\title{
Effect of heat challenge on peripheral blood mononuclear cell viability: comparison of a tropical and a temperate pig breed
}

\author{
Jean-Christophe Bambou ${ }^{\dagger}$, R. Grondin, Jean-Luc Gourdine and David Renaudeau
}

INRA, UR 143, 97170 Petit Bourg, Guadeloupe, France

Introduction

We evaluated the effect of heat challenge on peripheral mononuclear blood cells (PBMC) isolated from Creole (CR) and Large White (LW) pigs, on cell viability, concanavalin A-induced proliferation and heat shock proteins (HSP) mRNA expression.

\section{Material and methods}

PBMC from CR and LW growing pigs of 7 to 12 -weeks of age were isolated, cultured for 9 hours at $37^{\circ} \mathrm{C}$, and thereafter subjected to one of the three trials. In trial 1, cells from $18 \mathrm{CR}$ pigs and $18 \mathrm{LW}$ pigs were exposed to $42^{\circ} \mathrm{C}$ or $45^{\circ} \mathrm{C}$ for $2,4,6$ and 9 hours and cell viability was monitored. In trial 2, we evaluated mitogen-induced proliferation of PBMC from 5 CR pigs and 5 LW pigs after heat challenge for 2 and 9 hours at $45^{\circ} \mathrm{C}$ followed by 24 hour-stimulation at $37^{\circ} \mathrm{C}$ with concanavalin A. The aim of trial 3 was to measure induction of HSP70.2 and HSP90 mRNA expression in PBMC from 5 CR pigs and 5 LW pigs after heat challenge at $45^{\circ} \mathrm{C}$ for 3,6 and 9 hours.

\section{Results}

Viability was affected by breed and temperature $(P<0.01)$ but no effect of breed $\times$ temperature or breed $\times$ exposure time interactions was observed. The decrease in viability caused by heat challenge was greater for LW than for CR pigs. For mitogen-stimulated PBMC, incubation at $45^{\circ} \mathrm{C}$ reduced lymphoblastogenesis equally for both breeds $(P<0.001)$. Heat challenge for 6 hours at $45^{\circ} \mathrm{C}$ induced significant expression of HSP70.2 mRNA $(P<0.05)$ but no effect of exposure time was observed. Induction of HSP90 mRNA increased after heat challenge for 3 hours, and then decreased at 6 and 9 hours in both breeds $(P<0.01)$. A significant effect of exposure time was observed $(P<0.05)$. No effect of breed and breed $\times$ exposure time was observed for both HSP.

In conclusion, breed differences in resistance to heat challenge at the whole organism scale is reflected at the cellular level. Neither HSP70.2 nor HSP90 mRNA expression level could explain this effect.

\footnotetext{
${ }^{\dagger}$ E-mail: Jean-Christophe.Bambou@antilles.inra.fr
} 